Article

\title{
Key Role of Reactive Oxygen Species (ROS) in Indirubin Derivative-Induced Cell Death in Cutaneous T-Cell Lymphoma Cells
}

\author{
Marwa Y. Soltan ${ }^{1,2} \oplus$, Uly Sumarni ${ }^{1}$, Chalid Assaf ${ }^{1,3}$, Peter Langer ${ }^{4,5}$, Ulrich Reidel ${ }^{1}$ and \\ Jürgen Eberle ${ }^{1, *}$ \\ 1 Skin Cancer Centre Charité, Department of Dermatology and Allergy, Charité-Universitätsmedizin Berlin, \\ Charitéplatz 1, 10117 Berlin, Germany; Marwayassin@med.asu.edu.eg (M.Y.S.); \\ uly.sumarni@googlemail.com (U.S.); chalid.assaf@helios-gesundheit.de (C.A.); \\ ulrich.reidel@charite.de (U.R.) \\ 2 Department of Dermatology and Venereology, Faculty of Medicine, Ain Shams University, \\ Cairo 11591, Egypt \\ 3 Clinic for Dermatology and Venereology, Helios Klinikum Krefeld, Lutherplatz 40, 47805 Krefeld, Germany \\ 4 Institute of Chemistry, University of Rostock, Albert-Einstein-Str. 3a, 18059 Rostock, Germany; \\ peter.langer@uni-rostock.de \\ 5 Leibniz Institute of Catalysis at the University of Rostock e.V., Albert-Einstein-Str. 29a, \\ 18059 Rostock, Germany \\ * Correspondence: juergen.eberle@charite.de; Tel.: +49-30-450-518-383
}

Received: 8 February 2019; Accepted: 2 March 2019; Published: 7 March 2019

\begin{abstract}
Cutaneous T-cell lymphoma (CTCL) may develop a highly malignant phenotype in its late phase, and patients may profit from innovative therapies. The plant extract indirubin and its chemical derivatives represent new and promising antitumor strategies. This first report on the effects of an indirubin derivative in CTCL cells shows a strong decrease of cell proliferation and cell viability as well as an induction of apoptosis, suggesting indirubin derivatives for therapy of CTCL. As concerning the mode of activity, the indirubin derivative DKP-071 activated the extrinsic apoptosis cascade via caspase- 8 and caspase- 3 through downregulation of the caspase antagonistic proteins c-FLIP and XIAP. Importantly, a strong increase of reactive oxygen species (ROS) was observed as an immediate early effect in response to DKP-071 treatment. The use of antioxidative pre-treatment proved the decisive role of ROS, which turned out upstream of all other proapoptotic effects monitored. Thus, reactive oxygen species appear as a highly active proapoptotic pathway in CTCL, which may be promising for therapeutic intervention. This pathway can be efficiently activated by an indirubin derivative.
\end{abstract}

Keywords: CTCL; apoptosis; cell viability; c-FLIP; XIAP

\section{Introduction}

Reactive oxygen species (ROS) play important roles in tissue damage and aging, as also addressed in this special issue. On the other hand, an increasing number of scientific studies in recent years indicated a particular role of ROS in apoptosis regulation in cancer cells. The mechanism(s) are still under discussion. Here, we give an example of cutaneous T-cell lymphoma (CTCL), where ROS is induced by the drug candidate indirubin.

Non-Hodgkin's lymphomas (NHL) have shown increasing incidence in the last decades. About $5 \%$ of NHL are characterized by primary cutaneous manifestation through clonal proliferation of skin-homing memory T cells. This group of cutaneous T-cell lymphomas (CTCL) encloses Mycosis 
fungoides, Sézary syndrome and CD30(+) lymphoproliferative disorders. Cutaneous T-cell lymphomas represent a clinically and biologically distinct group of NHL without evidence for systemic disease at the time of first diagnosis. In clinical appearance and prognosis, they are clearly different from the histotypically cognate systemic lymphomas and their possible secondary cutaneous manifestations. Typically, they have the immunophenotype of CD3+ CD4+ CD45RO+ memory T-lymphocytes. While in its early stage CTCL may show an also indolent clinical course, it frequently transforms to a rapidly growing, malignant phenotype in later phases [1,2]. New treatments are needed particularly for these patients.

The elimination of tumor cells through the induction of apoptosis represents a principle goal in cancer treatment, and therapy resistance can thus be frequently explained by apoptosis deficiency [3]. Also, established therapies for CTCL as UV radiation or extracorporal photopheresis aim at an induction of apoptosis in tumor cells [4]. Extrinsic proapoptotic pathways are initiated by death ligands as CD95L/FasL or TRAIL (TNF-related apoptosis-inducing ligand), which also contribute to self-control of lymphocytes. Their binding to death receptors results in the formation of a death-inducing signaling complex, where initiator caspase- 8 is activated [5]. Caspase- 8 activation can be prevented by the competitive inhibitor protein c-FLIP (cellular FLICE-inhibitory protein) [6]. Initiator caspase-8 may cleave and activate the main effector caspase-3, which itself cleaves a large number of death substrates with the final result of DNA fragmentation [7]. Caspase-3 is negatively regulated through the binding of XIAP (chromosome X-linked inhibitor of apoptosis protein) [8].

In CTCL cells, the activation of the extrinsic caspase cascade plays a decisive role in controlling apoptosis. Thus, apoptosis resistance is correlated with reduced expression of the death receptor CD95/FAS [9] as well as with high and constitutive expression of c-FLIP [10]. Also, activation of the pro-survival transcription factors NF- $\mathrm{kB}$ [11] and STAT3 [12] were reported. In particular, different therapeutic strategies as NSAIDs, SAHA (suberoylanilide hydroxamic) and pentoxifylline resulted in downregulation of c-FLIP and XIAP in CTCL cells [13-15]. Finally, reactive oxygen species (ROS) may contribute to the regulation of apoptosis $[16,17]$. This is also suggested by enhanced levels of singlet oxygen $\left({ }^{1} \mathrm{O}_{2}\right)$ in the course of photodynamic therapy (PDT), used for the treatment of actinic keratosis $[18,19]$ and also considered for CTCL [20]. However, the relation of ROS with described apoptosis pathways is still largely elusive.

The natural compound indirubin and a number of reported chemical derivatives are considered as candidates for cancer therapy. Indirubin was identified as an active component in a traditional Chinese medicine remedy (Danggui Longhui Wan), also applied for chronic myeloid leukemia. In clinical trials, indirubin has shown significant antitumor activity in chronic myeloid and chronic granulocytic leukemia [21,22]. Explaining the mode of action, a large number of intracellular targets have been described for indirubin derivatives, including cyclin-dependent kinases (CDK1, CDK2, CDK4 and CDK5), pRb, glycogen synthase kinase 3 (GSK-3), STAT3 (Signal transducer and activator of transcription), EGFR (Epidermal growth factor receptor), c-Jun, and JNK2 [23-26]. The activation of extrinsic apoptosis pathways by indirubin derivatives was found in melanoma cells $[27,28]$. To improve the anti-cancer activity of indirubin, we have previously introduced a series of chemical modifications [29-31]. Here, we investigated the direct effects of the indirubin derivative DKP-071 in CTCL cells. We furthermore unraveled its mode of action, which is based on caspase activation, downregulation of the caspase antagonists c-FLIP and XIAP and, in particular, on early production of ROS.

\section{Results}

\subsection{Decreased Cell Proliferation and Viability Along with Induced Apoptosis by DKP-071}

Synthesis and structural aspects of the indirubin derivative DKP-071/substance 9d (Figure 1a) have been reported previously [31]. Here, its effects in three CTCL cell lines MyLa, HuT-78 and $\mathrm{HH}$ were investigated. These cell lines are characterized by the formation of cell clusters, a typical 
lymphocyte differentiation step [32,33]. In a first approach, we observed reduced cell cluster size in response to DKP-071, likely indicating reduced T-cell activity (Figure 1b). In line with this, cell proliferation was significantly reduced at $24 \mathrm{~h}$, as determined by WST-1 assay (Figure 1c). Reduced cell numbers were however not due to direct cytotoxicity, as lactate dehydrogenase (LDH) release assays at $24 \mathrm{~h}$ did not show a significant increase in MyLa or in $\mathrm{HH}$ cells (Figure 1d).

a
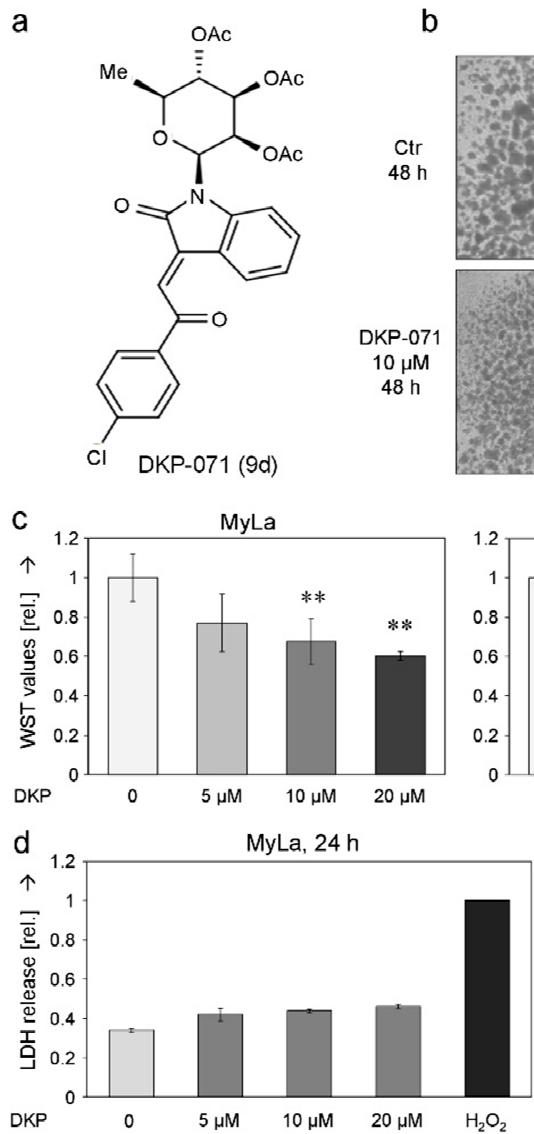

b
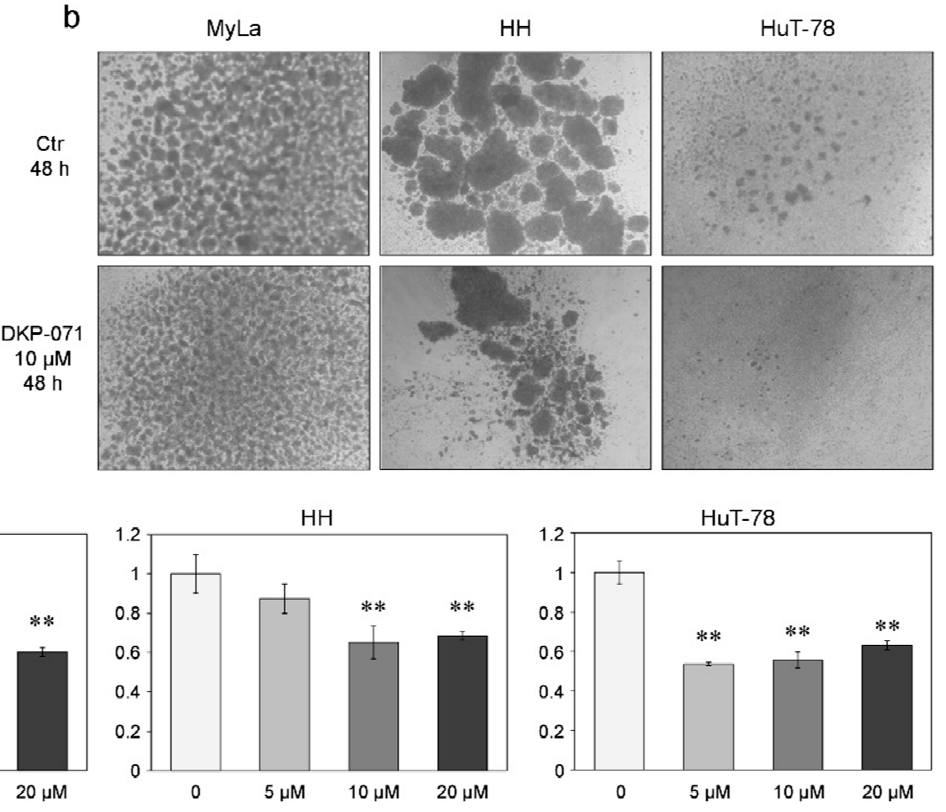

$\mathrm{HH}, 24 \mathrm{~h}$

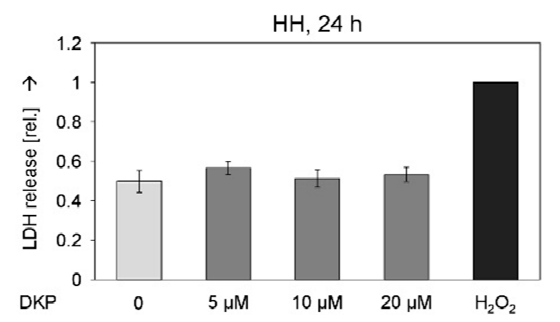

Figure 1. Decreased cell proliferation of CTCL cells by DKP-071. (a) Chemical structure of the indirubin derivative DKP-071 (termed substance 9d in [31]). (b) Cell cluster formation in CTCL cell lines MyLa, HuT-78 and HH. Control cells (Ctr) are shown vs. cells treated for $48 \mathrm{~h}$ with $10 \mu \mathrm{M} \mathrm{DKP-071}$ (magnification: 1:40). Many independent experiments showed the same result. (c) Cell proliferation of MyLa, HuT-78 and HH, at $24 \mathrm{~h}$ in response to treatment with 5, 10 and $20 \mu \mathrm{M}$ DKP-071 (DKP). Cell proliferation data were determined by WST-1 assay, and values are shown in relation (rel) to negative controls $(0)$, which were set to " 1 ". Statistical significance is indicated $(* * p 0.01)$. (d) Cytotoxicity was determined at $24 \mathrm{~h}$ in MyLa and in HH cells by LDH release assay. Values are shown in relation (rel) to $\mathrm{H}_{2} \mathrm{O}_{2}$-treated positive controls, which were set to " 1 ".

Cell viability, as determined by calcein staining, was strongly decreased. A dose dependency $(5-20 \mu \mathrm{M})$ was shown for MyLa and HH cells. At $48 \mathrm{~h}$ of treatment, $10 \mu \mathrm{M}$ DKP-071 reduced the numbers of viable cells to $23 \%$ (MyLa), $9 \%$ (HuT-78) and 38\% (HH), respectively (Figure 2a). Based on cell viability data, we calculated IC50 values of $7 \mu \mathrm{M}$ DKP-071 for Myla and $11 \mu \mathrm{M}$ for HH. For HuT-78, we used the WST data of Figure 1c, which resulted in an IC50 value of $8 \mu \mathrm{M}$ for HuT-78. Loss of cell viability went along with an induction of apoptosis, which was determined by counting sub-G1 cells in cell cycle analyses. Induction of apoptosis showed a comparable dose dependency. At $48 \mathrm{~h}$ of treatment, $10 \mu \mathrm{M}$ DKP-071 induced apoptosis in 17\% (MyLa), 24\% (HuT-78) and 22\% of HH cells, respectively (Figure 2b). The concentration of $10 \mu \mathrm{M}$ was selected for subsequent experiments. 


\subsection{Changes of Mitochondrial Membrane Potential and ROS Production}

Questioning the mechanisms that mediate the antineoplastic effects of DKP-071 in CTCL cells, we determined the relative changes in the mitochondrial membrane potential (MMP) as well as relative levels of reactive oxygen species (ROS) in response to treatment. Loss of MMP, indicative for an activation of mitochondrial apoptosis pathways, already started in the three cell lines at $5 \mathrm{~h}$ (31-49\%) but was much more evident at later time ( $24 \mathrm{~h}, 90 \%$ cells with low MMP; Figure 3a).

Reactive oxygen species (ROS) may mediate independent cell death pathways in cancer cells which are not yet completely understood [16]. Earlier than the loss of MMP, ROS levels were already strongly enhanced after $2 \mathrm{~h}$. Thus, 87\%, 83\% and 57\% of MyLa, HuT-78 and HH cells, respectively, showed high ROS levels at $2 \mathrm{~h}$ of DKP-071 treatment (Figure $3 \mathrm{~b}$ ).
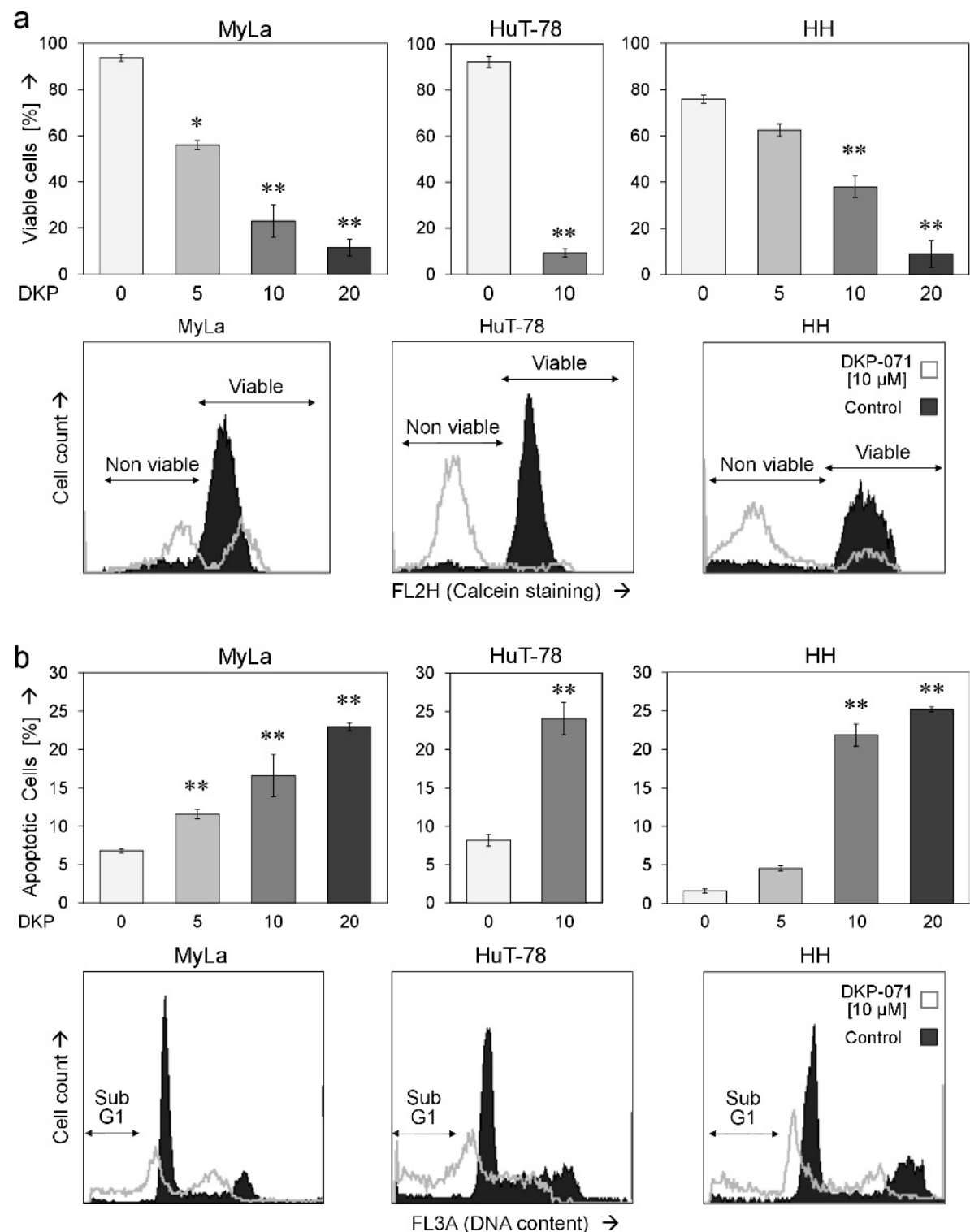

Figure 2. Reduced cell viability and induction of apoptosis. (a) Cell viability and (b) apoptosis were determined in three cell lines, in response to $48 \mathrm{~h}$ treatment with DKP-071 (5, 10 and $20 \mu \mathrm{M}$ for MyLa and $\mathrm{HH}$ as well as $10 \mu \mathrm{M}$ for HuT-78). Values were determined by calcein staining (a) and propidiumiodide staining (b), respectively. Characteristic histograms are shown for each cell line (10 $\mu \mathrm{M}$ treatment, overlays with controls); fractions of non-viable and viable as well as of apoptotic cells (sub-G1) are indicated. Mean values of triplicates $+/-$ SDs of a representative experiment are shown. Statistical significance is indicated (treated cells vs. controls; ${ }^{*} p<0.05 ;{ }^{* *} p<0.01$ ). 
a
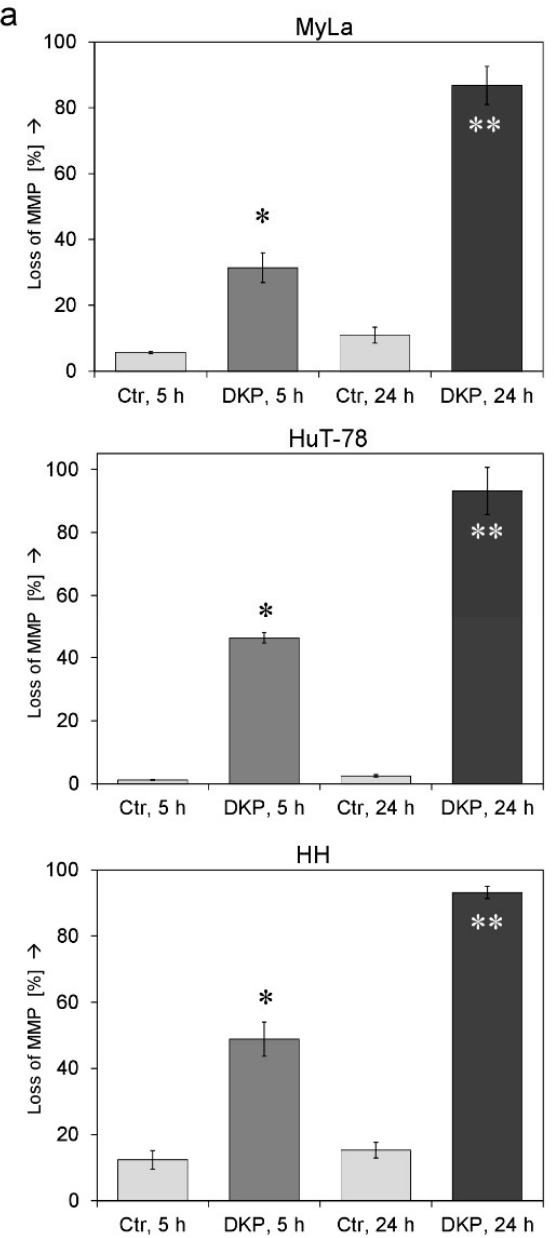
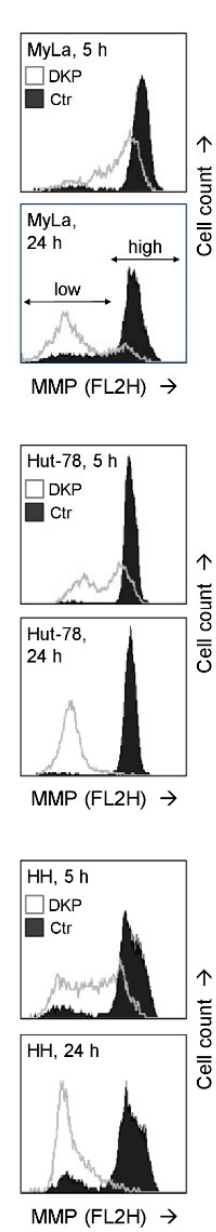

b
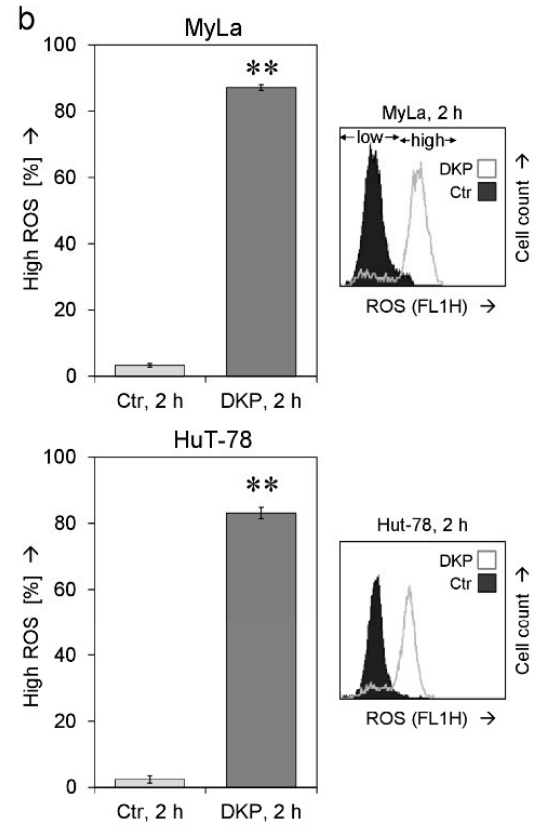

$\mathrm{HH}$

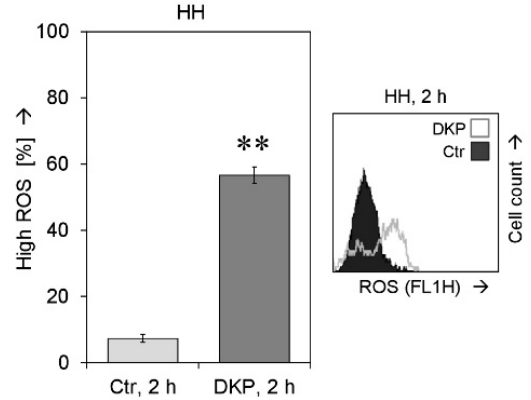

Figure 3. Effects on mitochondrial membrane potential and on ROS levels. (a) Relative changes in mitochondrial membrane potential (MMP) were determined at $5 \mathrm{~h}$ and $24 \mathrm{~h}$ in three CTCL cell lines in response to treatment with DKP-071 $(10 \mu \mathrm{M})$. Mean values of triplicates +/ - SD are shown; a second independent experiment series of MyLa revealed highly comparable results. Representative histograms (overlays of treated cells vs. controls) are given on the right side. (b) ROS levels were determined at $2 \mathrm{~h}$ of treatment. Mean values of triplicates +/ - SD are shown; for MyLa, three independent experiments, each one with triplicates, revealed highly comparable results. Representative histograms (overlays of treated cells vs. controls) are given on the right side. Statistical significance is indicated (treated cells vs. controls; $\left.{ }^{*} p<0.05 ;{ }^{* *} p<0.01\right)$.

\subsection{Critical role of ROS for Proapoptotic Effects of DKP-071}

To prove the significance of ROS as well as of caspase activation for the antineoplastic effects, the antioxidants tocopherol (vitamin E, VE) and N-acetyl cysteine (NAC) as well as the pan-caspase inhibitor QVD-Oph were applied. ROS production in response to DKP-071 was slightly reduced by $\mathrm{VE}$ and was strongly reduced by NAC, as shown in MyLa at $2 \mathrm{~h}$. Most effective was a combination of VE and NAC (both at $2 \mathrm{mM}, \mathrm{VE} / \mathrm{NAC}$ ), which completely abolished ROS production after DKP-071 treatment in the three cell lines. QVD-Oph remained without effect on ROS, indicating that ROS was independent of caspase activity (Figure 4).

ROS scavenging by VE/NAC proved the significant and upstream role of ROS for DKP-071-mediated effects. Thus, cell proliferation, which was decreased by DKP-071 at $24 \mathrm{~h}$, was restored in three cell lines by VE/NAC (Figure 5a). Similarly, the effects of DKP-071 on cell viability were strongly diminished by VE/NAC as shown in MyLa at $48 \mathrm{~h}$ (from $4 \%$ to $78 \%$ viable cells, Figure 5b). Finally, the induction of apoptosis, induced by DKP-071 in MyLa at $48 \mathrm{~h}(35 \%)$, was completely prevented by VE/NAC ( $3 \%$, Figure 5 c). Caspase inhibition through QVD-Oph 
also diminished apoptosis and loss of cell viability, which was, however, less effective than the antioxydative treatment (Figure $4 \mathrm{~b}, \mathrm{c}$ ). These findings support the explanation that ROS production was an upstream step.
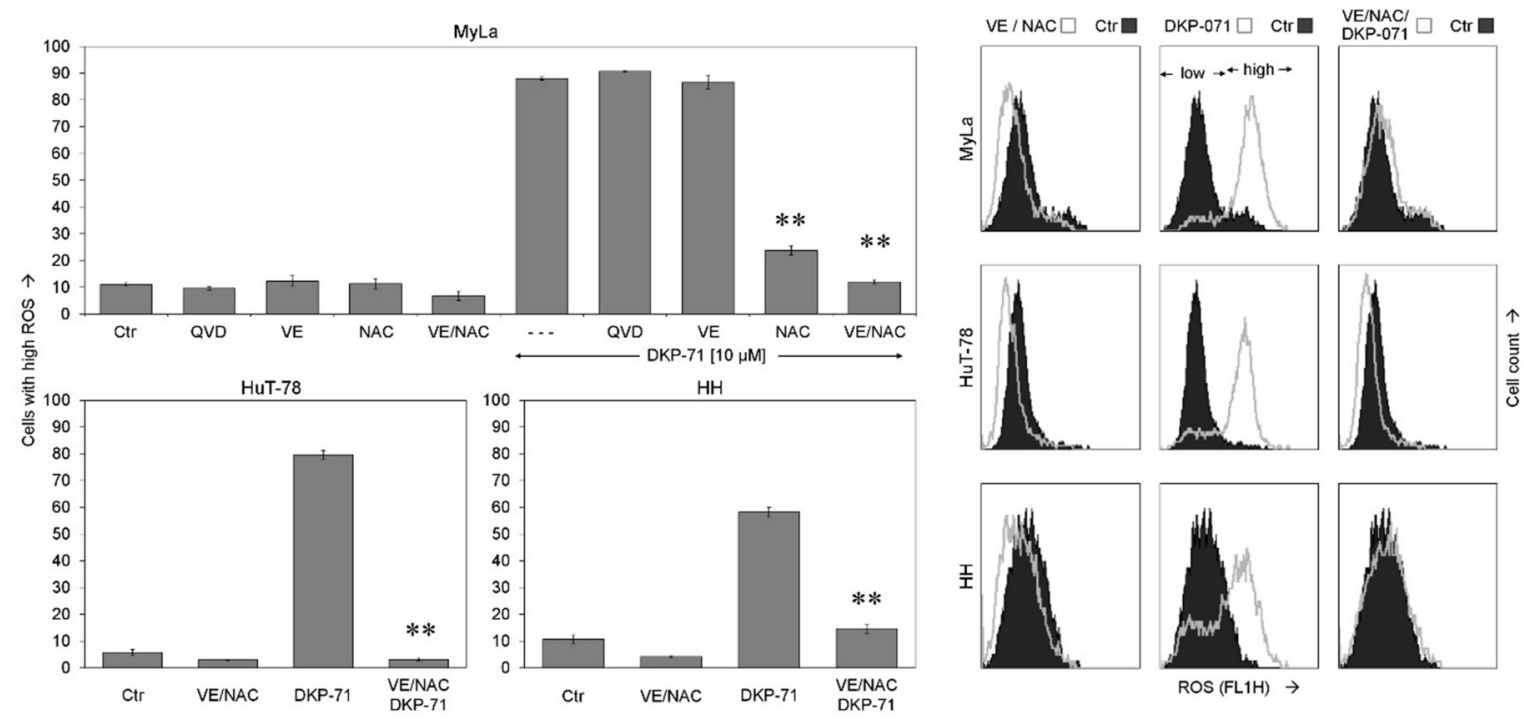

Figure 4. ROS suppression by antioxidative treatment. ROS levels are shown in MyLa in response to DKP-071 $(10 \mu \mathrm{M})$. In addition, antagonists as vitamin $\mathrm{E}(\mathrm{VE}, 1 \mathrm{mM}), \mathrm{N}$-acetyl cysteine (NAC, $1 \mathrm{mM})$, the pancaspase inhibitor QVD-Oph (QVD, $10 \mu \mathrm{M})$, as well as combined NAC and VE (each $2 \mathrm{mM}$ ) were applied $1 \mathrm{~h}$ before DKP-071 treatment was started. Cells which received only DKP-071 but no antagonist are indicated by (- - ). The antioxidative effect was also shown in HuT-78 and in HH by the use of VE/NAC. Mean values of triplicates +/ - SD of a representative experiment are shown; for MyLa, three independent experiments, each one with triplicates, revealed highly comparable results. Examples of flow cytometry measurement are shown on the right side as overlays versus control. Statistical significance of the differences of DKP-071/NAC-treated cells as well as DKP-071/VE/NAC-treated cells is indicated, each compared to the cells that received only DKP-071 $\left.{ }^{* *} p<0.01\right)$.
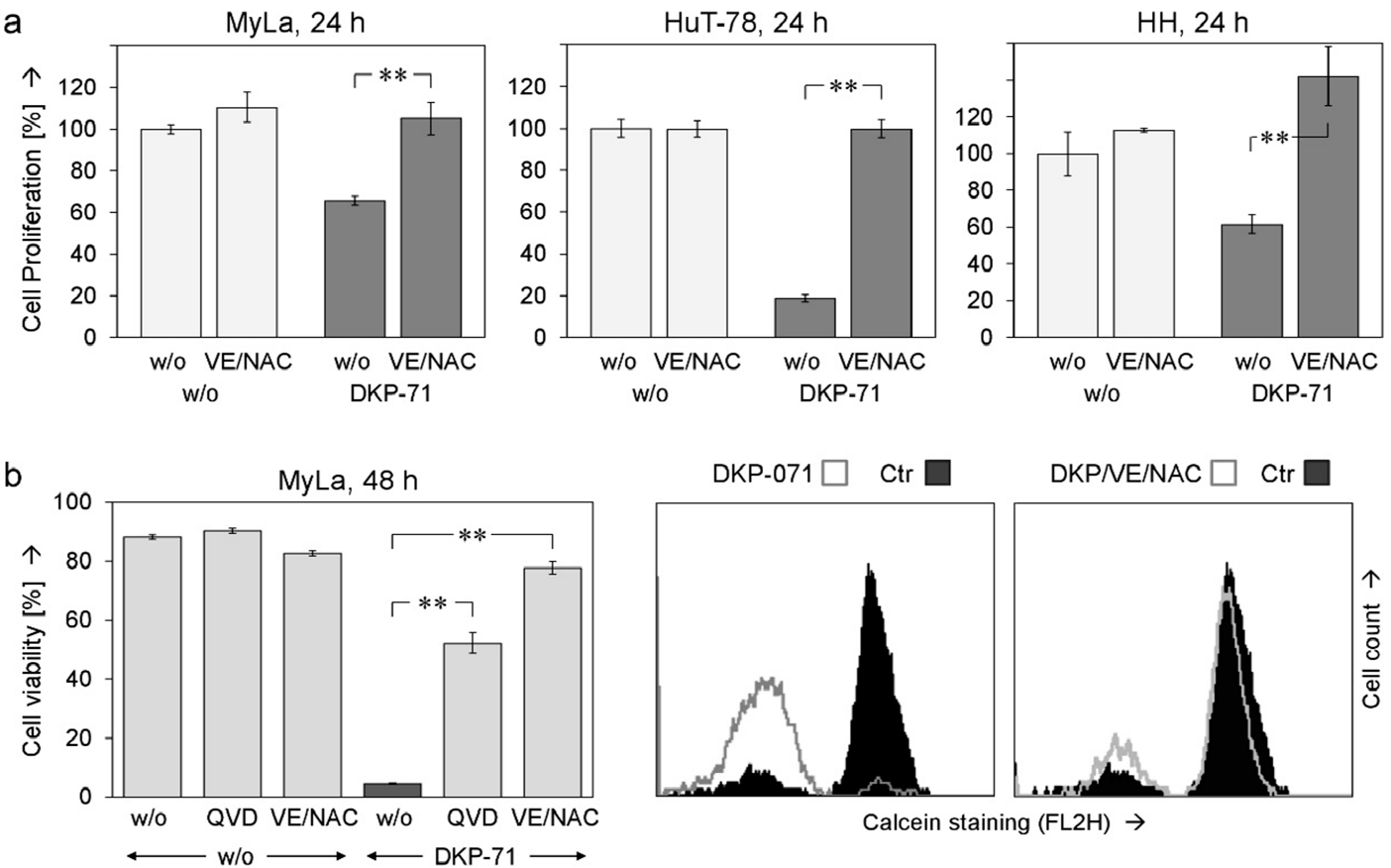

Figure 5. Cont. 

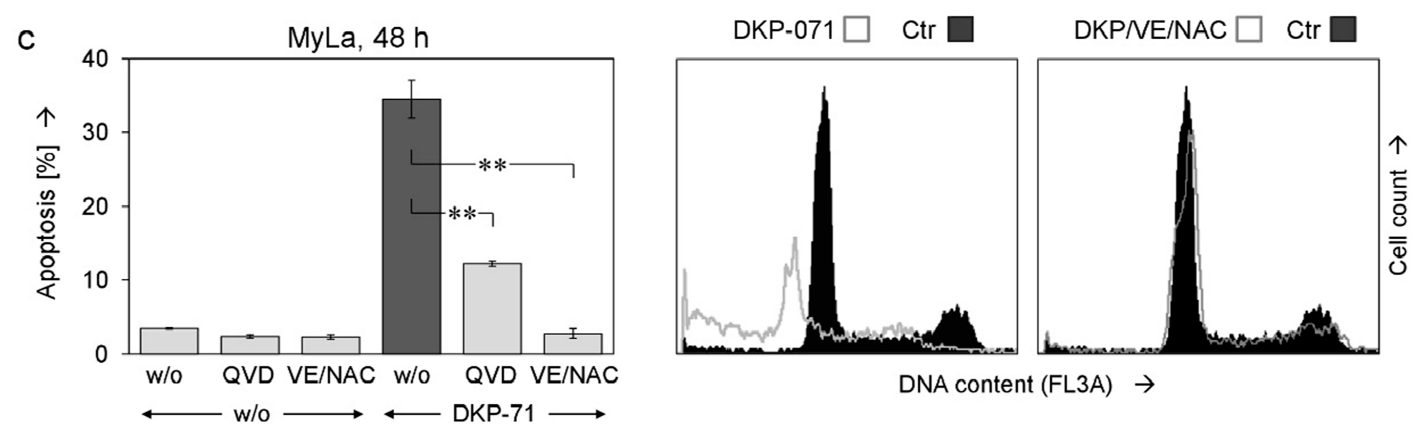

Figure 5. ROS suppression prevents apoptosis and restores cell viability. (a) Cell proliferation was determined at $24 \mathrm{~h}$ in response to DKP-071 as well as in response to the combination of NAC and VitE (2 mM; VE/NAC). Values were normalized to non-treated controls $(100 \%)$. (b,c) Effects of agonists and antagonists on apoptosis induction (b) and cell viability (c), both at $48 \mathrm{~h}$, are shown for MyLa cells. Examples of flow cytometry measurement are shown on the right side as overlays of treated cells versus controls. Mean values of triplicates +/ - SD of representative experiments are shown; at least two independent experiments, each one with triplicates, revealed highly comparable results. Statistical significance of the differences between DKP-071/VE/NAC-treated cells to cells that received only DKP-071 is indicated $(* * p 0.01)$.

\subsection{Role of Caspases and Caspase Antagonistic Proteins}

ROS also appeared upstream of MMP loss. Thus, VE/NAC almost completely prevented the loss of MMP in MyLa at $5 \mathrm{~h}(24 \%$ to $7 \%)$ whereas caspase inhibition was less effective here (18\%, Figure 6a). Extrinsic caspase pathways are of major importance for apoptosis regulation in lymphoma cells, also including CTCL [10]. Thus, we investigated by Western blotting the activation/processing of initiator caspase- 8 and the main effector caspase- 3 as well as the expression of the caspase- 3 antagonist XIAP and the caspase- 8 antagonist c-FLIP.

In response to $40 \mathrm{~h}$ treatment with DKP-071, the proform of caspase-8 (53/55 kD) disappeared, indicating its complete processing. In parallel, Caspase- 3 was processed to its mature, active cleavage product of $15 \mathrm{kDa}$. Importantly, VE/NAC strongly reduced the processing both of caspase- 8 and caspase-3. In particular, no active cleavage product of caspase-3 (15 kDa) was detected, but the processing was stopped at an intermediate product of $19 \mathrm{kDa}$. In clear contrast, QVD-Oph remained without effect on caspase-8. It, however, prevented caspase-3 autoprocessing and halted the cascade at the 19 and $17 \mathrm{kDa}$ intermediate cleavage products (Figure 6b, top). These findings clearly showed that ROS was upstream of any caspase regulation, while QVD-Oph acts downstream as a caspase-3 antagonist.

Explaining the activation of caspases, DKP-071 strongly reduced the expression of two most characteristic caspase antagonists, namely XIAP (51 kDa) and c-FLIP (long isoform, $52 \mathrm{kDa}$ and short isoform, $25 \mathrm{kDa}$ ). Of particular note, this downregulation was completely prevented by antioxidants (VE/NAC), while caspase-3 inhibition through QVD-Oph remained without effect on c-FLIP and XIAP (Figure 6b, bottom). Thus, ROS was also upstream of the downregulation of c-FLIP and XIAP. These findings suggest a cascade in CTCL cells, leading from ROS production in response to DKP-071 treatment to c-FLIP and XIAP downregulation and further to caspase activation and apoptosis (Figure 6c). 
a
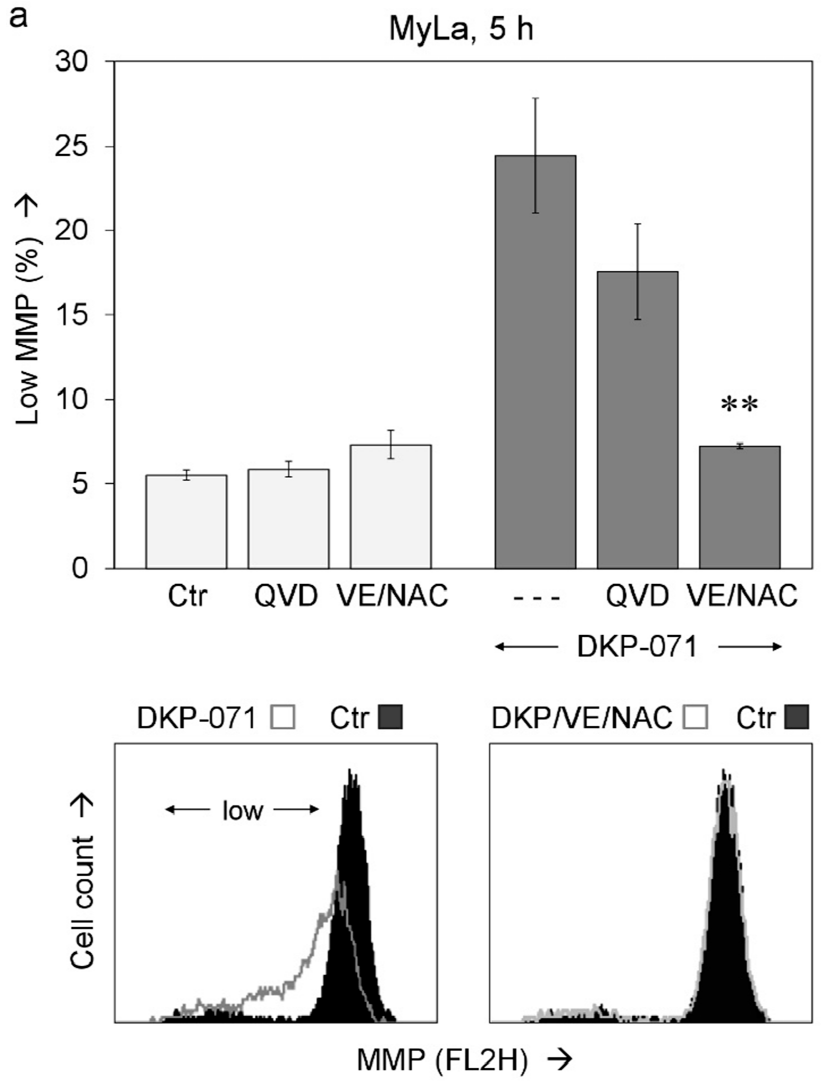

b

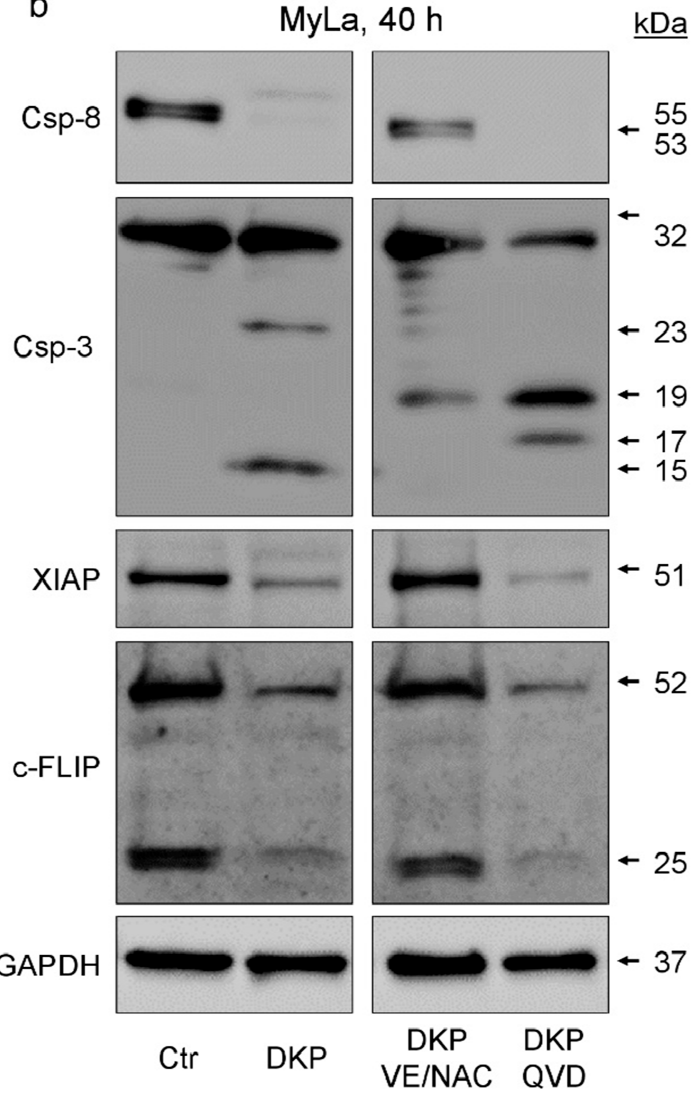

c

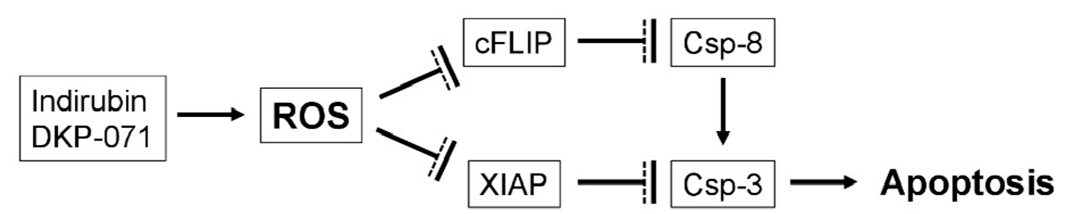

Figure 6. Effects on MMP and caspase cascade. (a) Effects of antioxidative treatment (VE/NAC, $2 \mathrm{mM}$ ) as well as of QVD-Oph (QVD, $10 \mu \mathrm{M})$ on mitochondrial membrane potential (MMP) are shown for MyLa cells at $5 \mathrm{~h}$ of DKP-071 treatment. Cells, which received only DKP-071 but no antagonist are indicated by (- - -). Mean values of triplicates +/ - SD of a representative experiment are shown; two independent experiments, each one with triplicates, revealed highly comparable results. Statistical significance of the differences between DKP-071/VE/NAC-treated cells to cells that received only DKP-071 is indicated $\left.{ }^{* *} p<0.01\right)$. Examples of flow cytometry measurement are shown below as overlays versus control. The cell population with low MMP is indicated. (b) Effects of DKP-071 and antioxidative pre-treatment on the expression of characteristic regulatory proteins of the extrinsic apoptosis caspase cascade were investigated by Western blotting. Each $30 \mu \mathrm{g}$ of protein was loaded per lane, and blots were probed with antibodies for extrinsic initiator caspase- 8 (proform, 53/55 kDa), main effector caspase-3 (proform, $32 \mathrm{kDa}$; cleavage products, 23, 19, 17, $15 \mathrm{kDa}$ ), caspase-3 antagonist XIAP (51 kDa) and caspase-8 antagonist c-FLIP (FLIP ${ }_{\mathrm{L}}$, long, $52 \mathrm{kDa}$; FLIP , short, $\left.25 \mathrm{kDa}\right)$. The housekeeping protein glyceraldehyde 3-phosphate dehydrogenase (GAPDH, $37 \mathrm{kDa}$ ) was used as loading control. Three independent series of protein extracts and Western blotting experiments revealed highly comparable results. (c) The pathway suggested for indirubin DKP-071-mediated apoptosis. Arrows indicate activation; blunt end lines indicate inhibition.

\section{Discussion}

Many new therapies established in recent decades for most tumors have sometimes dramatically enhanced patients' survival. Also for CTCL, present therapeutic options as topical steroids, bexarotene, phototherapy, interferon or some forms of targeted therapy have strongly improved the clinical 
outcome and often allow long-term survival. Nevertheless, in its late phase, CTCL may transform to a rapidly growing and ulcerating phenotype, characterized also by pronounced therapy resistance $[1,2]$. As apoptosis deficiency represents an in principal decisive issue in therapy resistance, the specific targeting of apoptosis pathways appears as a promising strategy [3].

Indirubin has been identified as the major component of a traditional Chinese medicine remedy, also applied for leukemia. In clinical trials for chronic myeloid and chronic granulocytic leukemia, it revealed significant antitumor activity, resulting in partial or complete remissions [21,22]. Chemical modifications of indirubin may further enhance its activity. Thus, we have recently reported the synthesis of new indirubin derivatives characterized by $\mathrm{N}$-glycosylated 3-alkylideneoxindol structures [31]. This first report on the effects of an indirubin derivative in CTCL cells shows a particular high activity resulting in decreased cell proliferation and cell viability as well as induction of apoptosis. There is no cutaneous non-tumorigenic T-cell line, which could be used for investigations in vitro and prove the tumor-specificity of the effects. However, due to the only moderate side effects reported for indirubin in clinical trials [21,22], the here investigated indirubin derivative may be suggested as a potential new therapeutic option for CTCL. A proapoptotic strategy, as by DKP-071, may also apply for early CTCL, characterized by an indolent clinical course and apoptosis susceptibility.

As concerning the pathways, by which indirubins may exert their effects, multiple targets have been suggested including CDKs, GSK-3 $\beta$, pRb, c-Src, FGF-R1, VEGFR, STAT3, c-Jun and JNK2 [23-26]. In melanoma cells, we have previously shown that indurubin derivatives enhance extrinsic apoptosis pathways as induced by TRAIL (TNF-related apoptosis-inducing ligand [27,28]. Extrinsic apoptosis pathways via caspase-8/caspase-3 are of particular importance for apoptosis regulation in CTCL cells [10,34]. Also in CTCL, DKP-071 mediated its proapoptotic effects via activation of the extrinsic caspase cascade, as shown by caspase- 8 and caspase- 3 processing as well as by the inhibition of the effects of indirubin through the caspase-3 antagonist QVD-Oph. Caspase activity is controlled by several antiapoptotic proteins such as the competitive caspase-8 antagonist c-FLIP and the protein family of cIAPs (cellular inhibitor of apoptosis proteins), e.g., the caspase- 3 antagonist XIAP (chromosome X-linked) [6,8]. These two antagonists appeared as essentially involved in the present setting, as strongly downregulated by DKP-071 in CTCL cells. Downregulation of these two factors in CTCL has also been reported by other treatments. Thus, c-FLIP was downregulated in response to SAHA (suberoylanilide hydroxamic) and NSAIDs, while XIAP was downregulated in response to SAHA and pentoxifylline [13-15].

Reactive oxygen species (ROS) play important roles in tissue damage and aging, and antioxidative strategies were established to prevent these negative effects. Besides this, ROS may also be involved in proapoptotic signaling in cancer cells $[16,28,35,36]$. As an example from the clinic, photodynamic therapy (PDT), used for the treatment of actinic keratosis, results in the production of high amounts of singlet oxygen. However, the role of ROS in PDT is still controversially discussed [18-20]. ROS may act as a signaling molecule e.g., by affecting the mitochondrial membrane and thus activating intrinsic, mitochondrial apoptosis pathways, or it may provoke cellular damage e.g., by oxidizing membrane lipids resulting in necrosis or activation of a damage response.

Here, we show even another alternative. In CTCL, ROS acts in cellular signaling clearly upstream of the extrinsic apoptosis pathway. It is induced already at $2 \mathrm{~h}$ in response to indirubin treatment and resides upstream of the downregulation of XIAP and c-FLIP as well as upstream of the loss of MMP, suggesting a signaling cascade as shown in Figure 6c. Also for other treatments in CTCL cells, relations of ROS and apoptosis induction have been reported, such as for an inhibitor of the antioxidative protein mucin 1 [37], for silencing of the enhancer of zeste homolog 2 (EZH2) [38] and for doxycycline [39]. Thus, ROS production appears to be an important cellular signaling step related to the induction of apoptosis. The new proapoptotic pathways behind this may be useful for targeted cancer therapy. In CTCL, our data suggest a strong relation between ROS, caspase antagonists and the activation of the extrinsic apoptosis pathway. This signaling cascade is efficiently triggered by the indirubin derivative DKP-071, suggesting it as a therapeutic strategy for CTCL. 


\section{Materials and Methods}

\subsection{Cell Culture and Treatments}

Three CTCL cell lines have been used here, which derive from patients with Mycosis fungoides and Sézary syndrome, respectively: Cell line MyLa was kindly supplied by Prof. K. Kaltoft, Århus University, Århus, DK. It derived from a plaque biopsy of a patient with MF [40]; HuT-78 was kindly supplied by Prof. R.C. Gallo, University of Maryland, Baltimore, MD, USA. [41] It derived from PBMCs of a patient with Sézary syndrome; and HH (CRL-2105, ATCC, Manassas, VA, USA) derived from peripheral blood of a patient with aggressive CTCL [42]. Cells were grown at $37^{\circ} \mathrm{C}, 5 \% \mathrm{CO}_{2}$ in RPMI 1640 medium supplemented with L-glutamine, 10\% FCS and antibiotics (Biochrom, Berlin, Germany). Under these applied conditions, the cell lines revealed a similar growth behavior and proliferation rate; only the formation of cell clusters, typical for T-cells, varied considerably (Figure 1a).

For assays, cells were seeded in 24-well culture plates $(100,000$ cells and $500 \mu \mathrm{L}$ per well) or in 96-well pates (40,000 cells and $200 \mu \mathrm{L}$ per well). For protein extraction, cells were seeded in 6-well plates (400,000 per well, $2 \mathrm{~mL}$ ). Treatments started at $24 \mathrm{~h}$ after seeding.

The indirubin derivative DKP-071 (termed substance 9d in [31]; Figure 1a) was used in concentrations of 5-20 $\mu \mathrm{M}$. For caspase inhibition, cells were pre-incubated for $1 \mathrm{~h}$ with the pan-caspase inhibitor QVD-Oph (Sigma-Aldrich, Taufkirchen, Germany, $10 \mu \mathrm{M}$ ). For ROS scavenging, cells were pre-treated for $1 \mathrm{~h}$ with $1 \mathrm{mM} \alpha$-tocopherol (vitamin E, Fluka, Steinheim, Germany), with $\mathrm{N}$-acetylcysteine (NAC; Sigma-Aldrich, Taufkirchen, Germany; $1 \mathrm{mM}$ ) or with a combination of vitamin $\mathrm{E}$ and NAC (VE/NAC; each $2 \mathrm{mM}$ ).

\subsection{Assays for Apoptosis, Cytotoxicity, Cell Viability and Cell Proliferation}

Apoptotic cells were quantified as sub-G1 cells (less DNA than G1 cells) in cell cycle analyses. The assay reveals less DNA in apoptotic cells, because small DNA fragments are washed out from isolated nuclei [43]. Cells were harvested by centrifugation, lysed and stained for at least $1 \mathrm{~h}$ in hypotonic PI solution ( $40 \mu \mathrm{g} / \mathrm{mL}$ propidium iodide, Sigma-Aldrich, in $0.1 \%$ sodium citrate, $0.1 \%$ Triton X-100). Stained isolated nuclei were analyzed by flow cytometry at FL3A with a FACS Calibur (BD Bioscience, Bedford, MA, USA). Cells in G1, G2 and S-phase as well as sub-G1 cells were determined.

Cell cytotoxicity was determined by the analysis of cell supernatants for the activity of lactate dehydrogenase (LDH), which is released from cytotoxic cells in culture. Aliquots of cell supernatants were collected at $24 \mathrm{~h}$, and LDH activity was quantified with a LDH activity assay (Cytotoxicity detection assay; Roche Diagnostics, Penzberg, Germany), following the protocol of the supplier. As positive controls, Triton X-100 (0.7\%)-treated cells were used. Relative values were determined in an ELISA reader. The increased LDH activity in treated wells traces back to damaged, cytotoxic cells.

Cell viability was determined by staining cells with calcein-AM (PromoCell, Heidelberg, Germany), which is a cell-permeant non-fluorescent substance that is converted to green-fluorescent calcein in live cells by the activity of intracellular esterases. Cells, grown and treated in 24-well plates, were harvested after $24 \mathrm{~h}$ or $48 \mathrm{~h}$ by centrifugation. After washing $1 \times$ with PBS, they were resuspended in $200 \mu \mathrm{L}$ of $2.5 \mu \mathrm{g} / \mathrm{mL}$ calcein-AM in PBS. Staining was done at $37^{\circ} \mathrm{C}$ for $1 \mathrm{~h}$. Labeled cells were washed again with $1 \mathrm{~mL}$ of PBS and were resuspended in $200 \mu \mathrm{L}$ PBS. The percentage of viable cells was determined by flow cytometry (FL2H). In the calcein assay, the total cell number does not contribute to the results, only the percentage of active cells in the remaining cell population is determined.

Cell proliferation was determined by WST-1 assay (Roche Diagnostics). It depends on the cleavage of the water-soluble tetrazolium salt by mitochondrial dehydrogenases in metabolically active cells. CTCL cells were seeded in 96-well plates, and treatments were started after $24 \mathrm{~h}$. At the time of analysis (24-48 h), WST-1 reagent was added for 1-2 h, and the absorbance at $450 \mathrm{~nm}$ was determined in an ELISA reader. Data were reported as the percentage of non-treated controls. The WST-1 assay gives an overview of all the antiproliferative effects of a given drug, which includes a lack of cells due to 
decreased cell proliferation as well as a lack of cells due to the induction of apoptosis or induction of cytotoxicity. Furthermore, the cell activity of the remaining cells contributes to the results.

\subsection{Mitochondrial Membrane Potential (MMP) and Reactive Oxygen Species (ROS)}

Changes to MMP over time or in response to drug treatment can be assessed by staining cells with the fluorescent dye TMRM ${ }^{+}$(Tetramethylrhodamin-methylester, Sigma-Aldrich). Due to its positive charge, $\mathrm{TMRM}^{+}$accumulates in negatively charged mitochondria. In the course of depolarisation of the mitochondria, (e.g., at the beginning of apoptosis), anions are released and $\mathrm{TMRM}^{+}$concentrations decrease. This staining may also be used to determine the effectiveness of therapeutic compounds [44]. Cells grown and treated in 24-well plates were harvested and stained for $20 \mathrm{~min}$ at $37^{\circ} \mathrm{C}$ with $1 \mu \mathrm{M}$ $\mathrm{TMRM}^{+}$. After two-times washing with PBS, cells were analyzed by flow cytometry (FL2H).

Intracellular ROS levels were determined by the cell-permeable substance $\mathrm{H}_{2}$ DCFDA ( $2^{\prime}, 7^{\prime}$-dichlorodihydrofluorescein diacetate; Thermo Fisher Scientific, Hennigsdorf, Germany). In cells with high ROS, the non-fluorescent $\mathrm{H}_{2}$ DCFDA is oxidized and thus converted in the strongly fluorescent DCF $\left(2^{\prime}, 7^{\prime}\right.$-Dichlorfluorescein). Cells grown in 24-well plates were pre-treated for $1 \mathrm{~h}$ with $\mathrm{H}_{2}$ DCFDA $(10 \mu \mathrm{M})$, before starting treatment with effectors. After treatment, cells were harvested by centrifugation, washed with $1 \mathrm{~mL}$ PBS, resuspended in PBS, and analyzed by flow cytometry (FL1H). As positive controls, cells were treated with $\mathrm{H}_{2} \mathrm{O}_{2}(1 \mathrm{mM}, 1 \mathrm{~h})$.

\subsection{Western Blotting}

For Western blotting, total protein extracts were obtained by cell lysis in $150 \mathrm{mM} \mathrm{NaCl}, 1 \mathrm{mM}$ EDTA, 2 mM PMSF, $1 \mathrm{mM}$ leupeptin, $1 \mathrm{mM}$ pepstatin, 0.5\% SDS, 0.5\% NP-40 and $10 \mathrm{mM}$ Tris-HCl, $\mathrm{pH}$ 7.5. Western blotting on nitrocellulose membranes was performed as described previously [45]. Primary antibodies: Cleaved caspase-3 (9664, rabbit, 1:1000, Cell Signaling, Danvers, MA, USA); XIAP (\#2042, rabbit, 1:1000, Cell Signaling); caspase-8 (\#9746; mouse, 1:1000, Cell Signaling); c-FLIP (G-11, sc-5276; Santa Cruz, Heidelberg, Germany; 1:50); and GAPDH (sc-32233, mouse, 1:1000, Santa Cruz Biotech). Secondary antibodies: peroxidase-labelled goat anti-rabbit and goat anti-mouse (Dako, Hamburg, Germany; 1:5000).

\subsection{Statistics}

Assays described above were performed in triplicate determinations, and usually at least two completely independent series were performed for each experiment. For the determination of statistical significance, the values of all individual experiments were given together, after normalizing according to the controls. A Student's $t$-test (two-tailed, heteroscedastic) was applied, and $p$-values of $<0.05$ were considered as statistically significant, while $p$-values of $<0.01$ were considered as highly significant. When applicable, significance is indicated in the bar charts $\left({ }^{*}\right.$ for $p<0.05$; ${ }^{* *}$ for $p<0.01$ ). The results of Western blots were reproduced in three independent series of experiments.

\section{Conclusions}

In summary, cutaneous T-cell lymphoma cells can be targeted by the induction of ROS. This results in an activation of the extrinsic apoptosis pathway via downregulation of c-FLIP and XIAP. This pathway is efficiently activated by an indirubin derivative, which thus represents an interesting candidate for therapy of cutaneous T-cell lymphoma.

Author Contributions: All authors have contributed to this work. M.Y.S. performed experiments, evaluations, literature screening and helped writing the manuscript; U.S. performed several experiments; C.A., P.L. and U.R. discussed the project and helped with writing the manuscript; P.L. also contributed with essential reagents; J.E. suggested the project, helped with the experiments, controlled all evaluations and wrote the manuscript.

Acknowledgments: Marwa Soltan received a scholarship from the Berlin Foundation for Dermatology (Berliner Stiftung für Dermatologie, BSD).

Conflicts of Interest: The authors declare no conflict of interest. 


\section{References}

1. Willemze, R.; Jaffe, E.S.; Burg, G.; Cerroni, L.; Berti, E.; Swerdlow, S.H.; Ralfkiaer, E.; Chimenti, S.; Diaz-Perez, J.L.; Duncan, L.M.; et al. WHO-EORTC classification for cutaneous lymphomas. Blood 2005, 105, 3768-3785. [CrossRef] [PubMed]

2. Jawed, S.I.; Myskowski, P.L.; Horwitz, S.; Moskowitz, A.; Querfeld, C. Primary cutaneous T-cell lymphoma (mycosis fungoides and Sezary syndrome): Part II. Prognosis, management, and future directions. J. Am. Acad. Dermatol. 2014, 70, 223.e1-223.e17. [CrossRef] [PubMed]

3. Eberle, J.; Kurbanov, B.M.; Hossini, A.M.; Trefzer, U.; Fecker, L.F. Overcoming apoptosis deficiency of melanoma-hope for new therapeutic approaches. Drug Resist. Updates 2007, 10, 218-234. [CrossRef] [PubMed]

4. Bladon, J.; Taylor, P.C. Extracorporeal photopheresis induces apoptosis in the lymphocytes of cutaneous T-cell lymphoma and graft-versus-host disease patients. Br. J. Haematol. 1999, 107, 707-711. [CrossRef] [PubMed]

5. Krammer, P.H.; Arnold, R.; Lavrik, I.N. Life and death in peripheral T cells. Nat. Rev. Immunol. 2007, 7, 532-542. [CrossRef] [PubMed]

6. Irmler, M.; Thome, M.; Hahne, M.; Schneider, P.; Hofmann, K.; Steiner, V.; Bodmer, J.L.; Schroter, M.; Burns, K.; Mattmann, C.; et al. Inhibition of death receptor signals by cellular FLIP. Nature 1997, 388, 190-195. [CrossRef] [PubMed]

7. Fischer, U.; Janicke, R.U.; Schulze-Osthoff, K. Many cuts to ruin: A comprehensive update of caspase substrates. Cell Death Differ. 2003, 10, 76-100. [CrossRef] [PubMed]

8. Deveraux, Q.L.; Takahashi, R.; Salvesen, G.S.; Reed, J.C. X-linked IAP is a direct inhibitor of cell-death proteases. Nature 1997, 388, 300-304. [CrossRef] [PubMed]

9. Wu, J.; Nihal, M.; Siddiqui, J.; Vonderheid, E.C.; Wood, G.S. Low FAS/CD95 expression by CTCL correlates with reduced sensitivity to apoptosis that can be restored by FAS upregulation. J. Investig. Dermatol. 2009, 129, 1165-1173. [CrossRef] [PubMed]

10. Braun, F.K.; Fecker, L.F.; Schwarz, C.; Walden, P.; Assaf, C.; Durkop, H.; Sterry, W.; Eberle, J. Blockade of death receptor-mediated pathways early in the signaling cascade coincides with distinct apoptosis resistance in cutaneous T-cell lymphoma cells. J. Investig. Dermatol. 2007, 127, 2425-2437. [CrossRef] [PubMed]

11. Sors, A.; Jean-Louis, F.; Pellet, C.; Laroche, L.; Dubertret, L.; Courtois, G.; Bachelez, H.; Michel, L. Down-regulating constitutive activation of the NF-kappaB canonical pathway overcomes the resistance of cutaneous T-cell lymphoma to apoptosis. Blood 2006, 107, 2354-2363. [CrossRef] [PubMed]

12. Eriksen, K.W.; Kaltoft, K.; Mikkelsen, G.; Nielsen, M.; Zhang, Q.; Geisler, C.; Nissen, M.H.; Ropke, C.; Wasik, M.A.; Odum, N. Constitutive STAT3-activation in Sezary syndrome: Tyrphostin AG490 inhibits STAT3-activation, interleukin-2 receptor expression and growth of leukemic Sezary cells. Leukemia 2001, 15, 787-793. [CrossRef] [PubMed]

13. Braun, F.K.; Al-Yacoub, N.; Plotz, M.; Mobs, M.; Sterry, W.; Eberle, J. Nonsteroidal anti-inflammatory drugs induce apoptosis in cutaneous T-cell lymphoma cells and enhance their sensitivity for TNF-related apoptosis-inducing ligand. J. Investig. Dermatol. 2012, 132, 429-439. [CrossRef] [PubMed]

14. Al-Yacoub, N.; Fecker, L.F.; Mobs, M.; Plotz, M.; Braun, F.K.; Sterry, W.; Eberle, J. Apoptosis induction by SAHA in cutaneous T-cell lymphoma cells is related to downregulation of c-FLIP and enhanced TRAIL signaling. J. Investig. Dermatol. 2012, 132, 2263-2274. [CrossRef] [PubMed]

15. Gahlot, S.; Khan, M.A.; Rishi, L.; Majumdar, S. Pentoxifylline augments TRAIL/Apo2L mediated apoptosis in cutaneous T cell lymphoma (HuT-78 and MyLa) by modulating the expression of antiapoptotic proteins and death receptors. Biochem. Pharmacol. 2010, 80, 1650-1661. [CrossRef] [PubMed]

16. Quast, S.A.; Berger, A.; Eberle, J. ROS-dependent phosphorylation of Bax by wortmannin sensitizes melanoma cells for TRAIL-induced apoptosis. Cell Death Dis. 2013, 4, e839. [CrossRef] [PubMed]

17. Bauer, D.; Werth, F.; Nguyen, H.A.; Kiecker, F.; Eberle, J. Critical role of reactive oxygen species (ROS) for synergistic enhancement of apoptosis by vemurafenib and the potassium channel inhibitor TRAM-34 in melanoma cells. Cell Death Dis. 2017, 8, e2594. [CrossRef] [PubMed]

18. Zou, Z.; Chang, H.; Li, H.; Wang, S. Induction of reactive oxygen species: An emerging approach for cancer therapy. Apoptosis 2017, 22, 1321-1335. [CrossRef] [PubMed] 
19. Salmeron, M.L.; Quintana-Aguiar, J.; De La Rosa, J.V.; Lopez-Blanco, F.; Castrillo, A.; Gallardo, G.; Tabraue, C. Phenalenone-photodynamic therapy induces apoptosis on human tumor cells mediated by caspase- 8 and p38-MAPK activation. Mol. Carcinog. 2018, 57, 1525-1539. [CrossRef] [PubMed]

20. Salva, K.A.; Kim, Y.H.; Rahbar, Z.; Wood, G.S. Epigenetically Enhanced PDT Induces Significantly Higher Levels of Multiple Extrinsic Pathway Apoptotic Factors than Standard PDT, Resulting in Greater Extrinsic and Overall Apoptosis of Cutaneous T-cell Lymphoma. Photochem. Photobiol. 2018, 94, 1058-1065. [CrossRef] [PubMed]

21. Xiao, Z.; Hao, Y.; Liu, B.; Qian, L. Indirubin and meisoindigo in the treatment of chronic myelogenous leukemia in China. Leuk. Lymphoma 2002, 43, 1763-1768. [CrossRef] [PubMed]

22. Blazevic, T.; Heiss, E.H.; Atanasov, A.G.; Breuss, J.M.; Dirsch, V.M.; Uhrin, P. Indirubin and Indirubin Derivatives for Counteracting Proliferative Diseases. Evid. Based Complement. Altern. Med. 2015, 2015, 654098. [CrossRef] [PubMed]

23. Perabo, F.G.; Frossler, C.; Landwehrs, G.; Schmidt, D.H.; von Rucker, A.; Wirger, A.; Muller, S.C. Indirubin-3'-monoxime, a CDK inhibitor induces growth inhibition and apoptosis-independent up-regulation of survivin in transitional cell cancer. Anticancer Res. 2006, 26, 2129-2135. [PubMed]

24. Meijer, L.; Skaltsounis, A.L.; Magiatis, P.; Polychronopoulos, P.; Knockaert, M.; Leost, M.; Ryan, X.P.; Vonica, C.A.; Brivanlou, A.; Dajani, R.; et al. GSK-3-selective inhibitors derived from Tyrian purple indirubins. Chem. Biol. 2003, 10, 1255-1266. [CrossRef] [PubMed]

25. Zhen, Y.; Sorensen, V.; Jin, Y.; Suo, Z.; Wiedlocha, A. Indirubin-3'-monoxime inhibits autophosphorylation of FGFR1 and stimulates ERK1/2 activity via p38 MAPK. Oncogene 2007, 26, 6372-6385. [CrossRef] [PubMed]

26. Zhang, Y.; Du, Z.; Zhuang, Z.; Wang, Y.; Wang, F.; Liu, S.; Wang, H.; Feng, H.; Li, H.; Wang, L.; et al. E804 induces growth arrest, differentiation and apoptosis of glioblastoma cells by blocking Stat3 signaling. J. Neurooncol. 2015, 125, 265-275. [CrossRef] [PubMed]

27. Berger, A.; Quast, S.A.; Plotz, M.; Hein, M.; Kunz, M.; Langer, P.; Eberle, J. Sensitization of melanoma cells for death ligand-induced apoptosis by an indirubin derivative-Enhancement of both extrinsic and intrinsic apoptosis pathways. Biochem. Pharmacol. 2011, 81, 71-81. [CrossRef] [PubMed]

28. Zhivkova, V.; Kiecker, F.; Langer, P.; Eberle, J. Crucial role of reactive oxygen species (ROS) for the proapoptotic effects of indirubin derivative DKP-073 in melanoma cells. Mol. Carcinog. 2019, 58, 258-269. [CrossRef] [PubMed]

29. Libnow, S.; Methling, K.; Hein, M.; Michalik, D.; Harms, M.; Wende, K.; Flemming, A.; Kockerling, M.; Reinke, H.; Bednarski, P.J.; et al. Synthesis of indirubin-N'-glycosides and their anti-proliferative activity against human cancer cell lines. Bioorg. Med. Chem. 2008, 16, 5570-5583. [CrossRef] [PubMed]

30. Kunz, M.; Driller, K.M.; Hein, M.; Libnow, S.; Hohensee, I.; Ramer, R.; Hinz, B.; Berger, A.; Eberle, J.; Langer, P. Synthesis of thia-analogous indirubin N-Glycosides and their influence on melanoma cell growth and apoptosis. ChemMedChem 2010, 5, 534-539. [CrossRef] [PubMed]

31. Kleeblatt, D.; Becker, M.; Plötz, M.; Schonherr, M.; Villinger, A.; Hein, M.; Eberle, J.; Kunz, M.; Rahman, Q.; Langer, P. Synthesis and Bioactivity of N-glycosylated 3-(2-Oxo-2- arylethylidene)-indolin-2-ones. RSC Adv. 2015, 5, 20623-20633. [CrossRef]

32. Bang, K.; Lund, M.; Mogensen, S.C.; Thestrup-Pedersen, K. In vitro culture of skin-homing T lymphocytes from inflammatory skin diseases. Exp. Dermatol. 2005, 14, 391-397. [CrossRef] [PubMed]

33. Drexler, H.G.; Pommerenke, C.; Eberth, S.; Nagel, S. Hodgkin lymphoma cell lines: To separate the wheat from the chaff. Biol. Chem. 2018, 399, 511-523. [CrossRef] [PubMed]

34. Braun, F.K.; Hirsch, B.; Al-Yacoub, N.; Durkop, H.; Assaf, C.; Kadin, M.E.; Sterry, W.; Eberle, J. Resistance of cutaneous anaplastic large-cell lymphoma cells to apoptosis by death ligands is enhanced by CD30-mediated overexpression of c-FLIP. J. Investig. Dermatol. 2010, 130, 826-840. [CrossRef] [PubMed]

35. Chen, J.C.; Zhang, Y.; Jie, X.M.; She, J.; Dongye, G.Z.; Zhong, Y.; Deng, Y.Y.; Wang, J.; Guo, B.Y.; Chen, L.M. Ruthenium(II) salicylate complexes inducing ROS-mediated apoptosis by targeting thioredoxin reductase. J. Inorg. Biochem. 2019, 193, 112-123. [CrossRef] [PubMed]

36. Takasaki, T.; Hagihara, K.; Satoh, R.; Sugiura, R. More than Just an Immunosuppressant: The Emerging Role of FTY720 as a Novel Inducer of ROS and Apoptosis. Oxid. Med. Cell. Longev. 2018, 2018, 4397159. [CrossRef] [PubMed] 
37. Jain, S.; Washington, A.; Leaf, R.K.; Bhargava, P.; Clark, R.A.; Kupper, T.S.; Stroopinsky, D.; Pyzer, A.; Cole, L.; Nahas, M.; et al. Decitabine Priming Enhances Mucin 1 Inhibition Mediated Disruption of Redox Homeostasis in Cutaneous T-Cell Lymphoma. Mol. Cancer Ther. 2017, 16, 2304-2314. [CrossRef] [PubMed]

38. Yi, S.; Sun, J.; Qiu, L.; Fu, W.; Wang, A.; Liu, X.; Yang, Y.; Kadin, M.E.; Tu, P.; Wang, Y. Dual Role of EZH2 in Cutaneous Anaplastic Large Cell Lymphoma: Promoting Tumor Cell Survival and Regulating Tumor Microenvironment. J. Investig. Dermatol. 2017, 138, 1126-1136. [CrossRef] [PubMed]

39. Alexander-Savino, C.V.; Hayden, M.S.; Richardson, C.; Zhao, J.; Poligone, B. Doxycycline is an NF-kappaB inhibitor that induces apoptotic cell death in malignant T-cells. Oncotarget 2016, 7, 75954-75967. [CrossRef] [PubMed]

40. Kaltoft, K.; Bisballe, S.; Dyrberg, T.; Boel, E.; Rasmussen, P.B.; Thestrup-Pedersen, K. Establishment of two continuous T-cell strains from a single plaque of a patient with mycosis fungoides. In Vitro Cell. Dev. Biol. 1992, 28A, 161-167. [CrossRef] [PubMed]

41. Gootenberg, J.E.; Ruscetti, F.W.; Mier, J.W.; Gazdar, A.; Gallo, R.C. Human cutaneous T cell lymphoma and leukemia cell lines produce and respond to T cell growth factor. J. Exp. Med. 1981, 154, 1403-1418. [CrossRef] [PubMed]

42. Starkebaum, G.; Loughran, T.P., Jr.; Waters, C.A.; Ruscetti, F.W. Establishment of an IL-2 independent, human T-cell line possessing only the p70 IL-2 receptor. Int. J. Cancer 1991, 49, 246-253. [CrossRef] [PubMed]

43. Riccardi, C.; Nicoletti, I. Analysis of apoptosis by propidium iodide staining and flow cytometry. Nat. Protoc. 2006, 1, 1458-1461. [CrossRef] [PubMed]

44. Creed, S.; McKenzie, M. Measurement of Mitochondrial Membrane Potential with the Fluorescent Dye Tetramethylrhodamine Methyl Ester (TMRM). Methods Mol. Biol. 2019, 1928, 69-76. [PubMed]

45. Eberle, J.; Fecker, L.F.; Hossini, A.M.; Wieder, T.; Daniel, P.T.; Orfanos, C.E.; Geilen, C.C. CD95/Fas signaling in human melanoma cells: Conditional expression of CD95L/FasL overcomes the intrinsic apoptosis resistance of malignant melanoma and inhibits growth and progression of human melanoma xenotransplants. Oncogene 2003, 22, 9131-9141. [CrossRef] [PubMed]

(C) 2019 by the authors. Licensee MDPI, Basel, Switzerland. This article is an open access article distributed under the terms and conditions of the Creative Commons Attribution (CC BY) license (http:/ / creativecommons.org/licenses/by/4.0/). 